\title{
Factors Affecting Employee Performance during Work from Home
}

\author{
Vina Da'watul Aropah, Ma'mun Sarma, I Made Sumertajaya \\ Department of Management, Faculty of Management, Institut Pertanian Bogor
}

\begin{tabular}{|c|c|}
\hline ARTICLE INFO & A B S T RACT \\
\hline $\begin{array}{l}\text { Keywords: } \\
\text { Leadership } \\
\text { Work Environment } \\
\text { Organizational Support } \\
\text { Employee Performance } \\
\text { Work from Home. } \\
\\
\text { Kata Kunci: } \\
\text { Kepemimpinan, } \\
\text { Lingkungan kerja, } \\
\text { Dukungan Organisasi, } \\
\text { Kinerja Karyawan, } \\
\text { Bekerja dari Rumah }\end{array}$ & $\begin{array}{l}\text { The Corona Virus Disease (Covid-19) pandemic in Indonesia began with } \\
\text { the discovery of Covid-19 sufferers on March } 2,2020 \text {. Coronavirus is a group } \\
\text { of viruses that can cause disease in animals or humans. To respond the } \\
\text { conditions of the Covid-19 outbreak, NPPA issued a regulation concerning } \\
\text { adjustments to the work system of the government employee in efforts to } \\
\text { prevent the spread of Covid-19. This study uses census sampling, where } \\
\text { all members of the population used as samples. The total responden of } \\
\text { the Government Employee in NPPA is } 128 \text { employees, who are works } \\
\text { mostly at home during the pandemic. The research data used primary } \\
\text { and secondary data. Comparison using PLS-SEM as analyzing the data. } \\
\text { The result of the research showed that leadership and work environment } \\
\text { have impact on employee performance, whereas organizational support } \\
\text { has no impact on employee performance. }\end{array}$ \\
\hline
\end{tabular}

SARI PATI

Pandemi Corona Virus Disease (Covid-19) di Indonesia diawali dengan ditemukannya penderita Covid-19 pada 2 Maret 2020. Coronavirus merupakan kelompok virus yang dapat menyebabkan penyakit. pada hewan atau manusia. Menyikapi kondisi wabah Covid-19, NPPA mengeluarkan peraturan tentang penyesuaian sistem kerja Pegawai Negeri dalam upaya pencegahan penyebaran Covid-19. Penelitian ini menggunakan metode sensus sampling, dimana semua anggota populasi dijadikan sampel. Total populasi Pegawai Negeri di NPPA adalah 128 pegawai, yang bekerja lebih banyak di rumah selama pandemi. Data penelitian menggunakan data primer dan data sekunder. Perbandingan menggunakan PLS-SEM sebagai penganalisis datanya. Hasil penelitian menunjukkan bahwa kepemimpinan dan lingkungan kerja berpengaruh terhadap kinerja pegawai, sedangkan dukungan organisasi tidak berpengaruh terhadap kinerja pegawai. 


\section{INTRODUCTION}

The coronavirus disease (Covid-19) pandemic begins with the discovery of the identification of a novel coronavirus sufferer in China and the confirmation from Chinese authorities on 7 January 2020. Covid-19 outbreak was declared a public health emergency of international concern on 30 January 2020 (World Health Organization, 2020). Covid-19 pandemic in Indonesia began with the discovery of Covid-19 sufferers on March 2, 2020.

Covid-19 is a group of viruses that can cause disease in animals or humans. Several types of coronavirus are known to cause respiratory infections in humans ranging from cold coughs to more serious ones such as Middle East Respiratory Syndrome (MERS) and Severe Acute Respiratory Syndrome (SARS). Covid-19 can spread from person to person through droplets from the nose or mouth that come out when a person with Covid-19 coughs or exhales. These sparks then fall on objects and surrounding surfaces. The effective ways to prevent transmission of viruses are physical distancing, using face masks, and eye protection (Chu et al., 2020).

In connection with the massive pattern of Covid-19 and to anticipate the spread of Covid-19, Ministry of Administrative and Bureaucratic Reform (2020) in Indonesia issues a Circular Letter Number 19 of 2020 regarding adjustments to the work system. This regulation was then changed several times. The regulations have released one work method called regarding adjustments to the work system, namely working from home as a solution to protect employee health and maintain employee performance during the Covid-19 outbreak. Based on the work from home rules issued by the minister, National Public Procurement Agency (NPPA) has also issued the regulations related to adjustments the work system, namely working from home. NPPA issued Circular Letter Number 2 of 2020 and has made several changes. This regulation state that employees work from home during a pandemic. Work from home or teleworking in Covid-19 crisis has been used by companies to ensure their employees' safety and to provide continuity to economic activity (Belzunegui-Eraso \& Erro-Garcés, 2020).

The concept of work from home is actually not a new concept at work. Work from home or better known as telecommuting or teleworking was first introduced by Niles JM in 1973 (Nilles, 1988). Telecommuting refers to the partial or total substitution of telecommunications, with or without computer assistance. Telecommuting includes all the replacement of telecommunication and information technology for jobs. Telework has been defined as a flexible work arrangement in which workers work on location, away from the head office or production facilities, without personal contact with co-workers, but the ability to communicate with colleagues using information and communication technology (Di Martino \& Wirth, 1990). Telework, also known as work from home or mobile working, has attracted renewed attention due to the deployment of ICTs that make it possible to work wherever possible and practical (Kurland \& Bailey, 1999). Telecommuting refers to working at home or anywhere else the employee chooses that is outside the workplace at least 2 days a week on a computer linked to the employer's office (Robbins \& Judge A, 2017).

NPPA in dealing with Covid 19 uses a work from home policy as a way to maximize employee performance during the pandemic. One that affects the success of an organization is the performance of the employees. Therefore, NPPA seek to improve the performance of its employees in order to achieve organizational goals during the pandemic. Performance is the work result in quantity achieved by an employee in carrying out his duties according to his responsibilities. Most managers believe good performance means doing well on task performance. The criteria of evaluate employee performance popular in three criteria, that are individual task outcomes, behaviors, and traits. Task outcomes should evaluate on outcomes such as quantity and quality, behavior means evaluate 
the actions of employees in advisory or support positions such as pomptness time in work and traits means having a good attitude such as being dependable (Robbins \& Judge A, 2017).

Some opinions state that telework can increase employee productivity and performance. Telework has a positive effect on new performance through enabling knowledge sharing, cross-functional cooperation and inter-organizational involvement, telework improves the speed and quality of product development (Coenen \& Kok, 2014). Telework is perceived to increase productivity, secure retention, strengthen organizational commitment, and improve performance within the organization (Martin \& MacDonnell, 2012). Teleworking positively affects employee performance and company performance (Martínez-Sánchez, Pérez-Pérez, José Vela-Jiménez, \& de-Luis-Carnicer, 2008). The companies that use teleworking use more free time, have more employees involved in the design and planning of work, and are managed more intensively by the results they want to achieve. Furthermore, employees have a more positive work experience while teleworking, they have a higher levels of job performance and job satisfaction (Vega, Anderson, \& Kaplan, 2015). The critical success factor in teleworking is management support, communication, and trust. Management support includes organizational support, leadership and managed workspaces (Kowalski \& Swanson, 2005). Organization leaders, managers, and supervisors should consider employing strategies to address the challenges of teleworking (Burbach \& Day, 2012).

The purpose of study is to determine the factors that influence the concept of working form home in NPPA. The research conducted to find out the relationship of leadership, organizational support and work environment on employee performance.

\section{Transformational Leadership}

Leadership is a process where a person can become a leader through continuous activities so that it can influence who they lead in order to achieve organizational goals. Leadership is an important aspect as it usually enables the employees of the organizations to work efficiently and effectively (Agarwal, 2020). According to Cascio (2000) in virtual offices such as telework or work from home, the challenge for leaders is to establish and enforce ground rules for comprehensive communication and performance management processes. Communication is the biggest challenge for leaders to implement virtual working conditions. Leaders must learn how to conduct effective audio meetings and balance email, voicemail, video conferencing and face-to-face communication. Then the next challenge for leaders is to perform performance management for employees, and leaders must take several steps, namely: defining performance, facilitating performance, and encouraging performance (Cascio, 2000).

According to Brunelle (2013) physical distance and psychological distance have a negative impact on relational quality in mobile work conditions, but the level of transformational leadership can moderate this relationship by reducing the negative impact. Companies that want to implement mobile work must be careful in choosing people who will supervise their work or employees. They need to choose managers who are able to exercise transformational leadership, in other words, people who show empathy, good listening skills, have a vision, the ability to influence others, and the capacity to inspire and share with intellectual stimulation.

Transformational leadership is style of leadership that transforms followers to rise above their selfinterest by altering their morale, ideals, interests, and values, motivating them to perform better than initially expected (Pieterse, Van Knippenberg, Schippers, \& Stam, 2009). Transformational leaders have the ability to transform organizations through their vision for the future, and by clarifying their vision, they can empower the employees to take responsibility for achieving that vision (Kim, 2014). 


\section{Organizational Support}

According Aboelmaged, Mohamed, \& Subbaugh (2012) the critical factors influencing the perceived productivity of teleworkers are the role of individual and organizational factors. Job security, job satisfaction, work flexibility, organizational commitment and management support are emerged as key determinants of perceived teleworking productivity. For successful implementation of telework policy, the government should provide and improve necessary IT infrastructures including high speed internet and provide necessary training for both managers and employees (Valmohammadi, 2012). Telework organizational support namely the use of technology, support related to the use of technology and variables other than technology (Baker, Avery, \& Crawford, 2006). The use of technology consists of having sufficient IT support, which refers to assistance with technology- related problems and questions from the telecommuting employee and appropriate telecommuting technology. Support related to the use of technology consists of training for telecommuting employees, which involves instruction in technology use, for managers, coworkers, and household members, and the provision of financial support for telecommuter expenses. These expenses are generally for purchasing telecommuting technology or for its running costs. Variables other than technology that are unrelated to technology. Variables other than technology consists of trusted by their manager when they are working from home and not able to be observed directly by the manager, human resource department support for the telecommuting, and prior planning for telecommuting system from organization.

\section{Work Environment}

The work environment is included in a very important component for employees to carry out work activities. A conducive work environment is able to motivate employees to work and will have an impact on employee morale and performance. One of the most important telework factors impacting telework outcomes is suitability of the working place at home (Nakrošienè, Bučiūnienè, \& Goštautaitè, 2019). Work environment provides security and allows employees to work optimally, it can influence the emotions of the employee. Teleworkers who are work at home shows that workers want a quality work environment at home similar to a conventional office, such as having privacy, quality lighting, and adequate equipment ( $\mathrm{Ng} \& \mathrm{Ng}, 2010$ ). The physical workplace characteristics for mobile knowledge workers include amount of space, layout, ambient conditions and internet and $\mathrm{Wi}$ Fi connectivity ( $\mathrm{Ng}, 2016)$. One of strategies for overcoming telework challenges is prepare the physical/home environment, which included setting up an environment that is conducive to working, such as a dedicated workspace, sometimes with physical boundaries (e.g., a room with a door) (Greer \& Payne, 2014). Teleworkers manage the balance between their home and working lives by establishing temporal and physical boundaries (Mustafa \& Gold, 2013).

The theoretical base achieved from the reviewed literature and understanding of the concepts so far contributed to propose following hypotheses:

$\mathrm{H}_{1}$ : Leadership significantly affects employee performance in NPPA in connection with the work from home policy

$\mathrm{H}_{2}$ : Organizational support significantly affects employee performance in NPPA in connection with the work from home policy

$\mathrm{H}_{3}$ : Work Environment significantly affects employee performance in NPPA in connection with the work from home policy

\section{METHODS}

The type of data in this study are primary and secondary data. Primary data is obtained directly from employees at the NPPA by filling in the questionnaire. The number of government employee in NPPA is 273 employees, but government employees in the research period who carry out their work are mostly done from home, namely 128 employees or $46.88 \%$. The total responden of this study is 128 NPPA government employees, 
who worked at home almost $55 \%$ of the time during the pandemic. The sampling method is census. This research is conducted from June $26^{\text {th }}$ to August $14^{\text {th }} 2020$. This study uses the Partial Least Square Structural Equation Modelling (PLS-SEM). Secondary data are obtained through literature studies sourced from journals, theses, articles and books, the internet as well as data provided by institutions and relevant to this research. The research model is presented in Figure 1 below:

\section{RESULTS AND DISCUSSION}

\section{Analysis of Respondents' Descriptions}

The number of government employee in NPPA is 273 people, but not all government employee work from home. This research using respondents who carried out their work mostly from home in research periode or $55 \%$ of their attendance by working from home. The percentage of the number of employees as mentioned above is based on work units and positions as shown in Table 1.

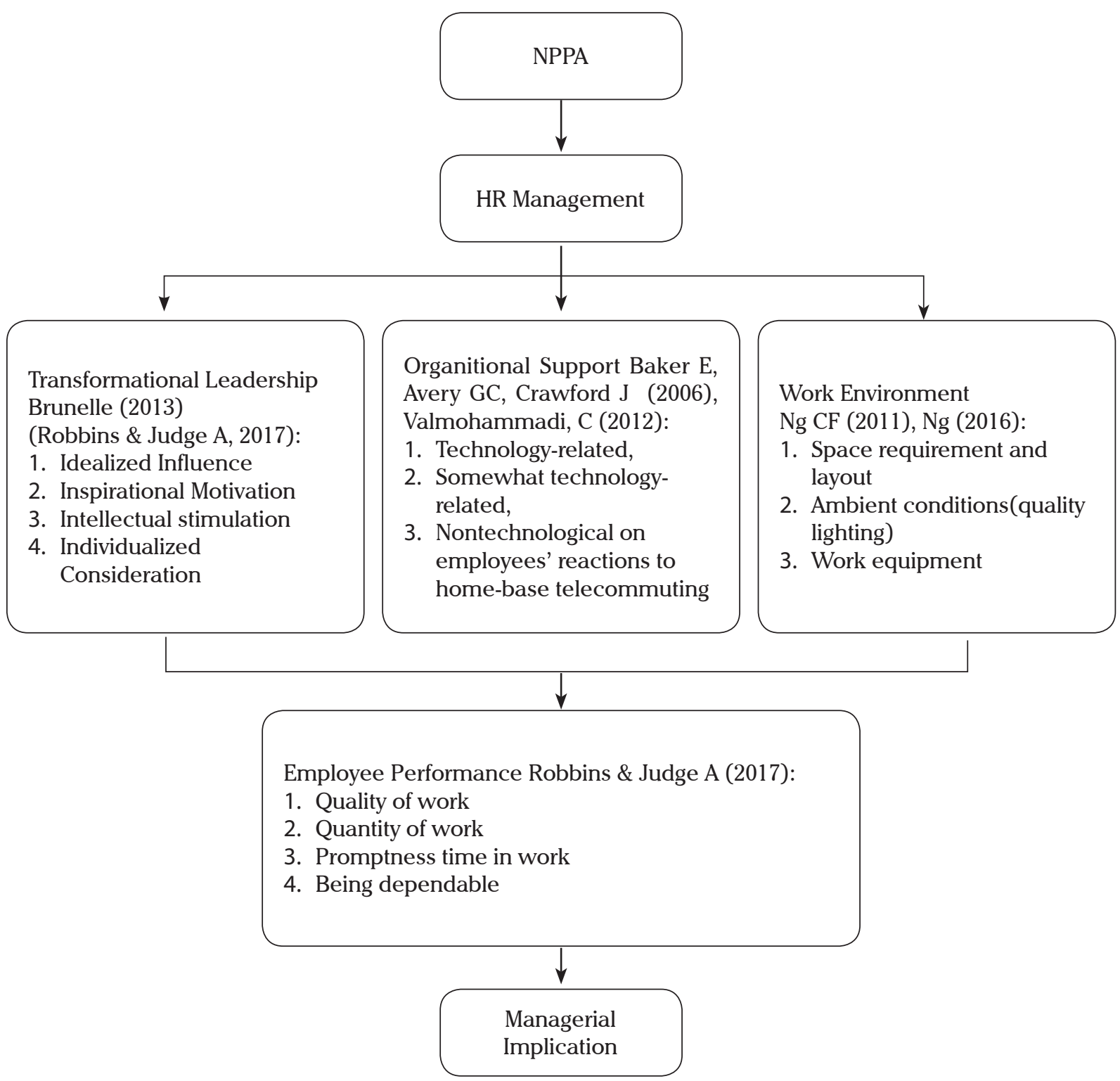

Figure 1. Research Framework 
Table 1. Number and Percentage of Respondents

\begin{tabular}{|c|c|c|c|c|}
\hline & Employee Characteristics & $\begin{array}{l}\text { Num. of } \\
\text { employee }\end{array}$ & $\begin{array}{l}\text { Num. of employee } \\
\text { is } 55 \% \text { WFH }\end{array}$ & $\begin{array}{l}\text { Percentage of } \\
\text { employees } 55 \% \\
\text { WFH }\end{array}$ \\
\hline \multirow[t]{10}{*}{ Work Unit } & Chair of the NPPA & 1 & 0 & $0.00 \%$ \\
\hline & Executive Secretariat & 82 & 29 & $35.37 \%$ \\
\hline & $\begin{array}{l}\text { Deputy Chair for Strategy and Policy } \\
\text { Development }\end{array}$ & 43 & 29 & $67.44 \%$ \\
\hline & $\begin{array}{l}\text { Deputy Chair for Monitoring Evaluation } \\
\text { and Development of Information Systems }\end{array}$ & 50 & 12 & $24.00 \%$ \\
\hline & $\begin{array}{l}\text { Deputy Chair for Human Resource } \\
\text { Development }\end{array}$ & 29 & 21 & $72.41 \%$ \\
\hline & $\begin{array}{l}\text { Deputy Chair for Legal Affairs and } \\
\text { Complaints Handling }\end{array}$ & 44 & 23 & $52 / 27 \%$ \\
\hline & Inspectorate & 9 & 0 & $0.00 \%$ \\
\hline & $\begin{array}{l}\text { Public Procurement Education and } \\
\text { Training Center }\end{array}$ & 15 & 14 & $93.33 \%$ \\
\hline & Echelon I/Senior High Officials & 5 & 2 & $40.00 \%$ \\
\hline & $\begin{array}{l}\text { Echelon II/Primary High Management } \\
\text { Officers }\end{array}$ & 16 & 2 & $12.5 \%$ \\
\hline \multirow[t]{3}{*}{ Position } & Echelon III/Administrator Officer & 32 & 13 & $40,62 \%$ \\
\hline & Echelon IV/Supervisory Officer & 68 & 34 & $50.00 \%$ \\
\hline & Staf/Implementing Officer & 151 & 77 & $50.99 \%$ \\
\hline \multicolumn{2}{|c|}{ Sum of Employee } & 273 & 128 & \\
\hline
\end{tabular}

Source : Primary data, processed (2020)

Based on data, it shows that not all government employees in the NPPA carry out work from home. The data show that there are 128 people who work from home or more than $55 \%$ of their attendance by working from home. Public Procurement Education and Training Center is a work unit which many employees work from home (93.33\%). Government employees with the position of Staff/Implementing Officer carry out the most work from home at $50.99 \%$, while only $40 \%$ of Echelon I/Senior High Officials and $12.5 \%$ of Echelon II/Primary High Management Officers carry out work from home.

The population of respondents in this study is government employees at NPPA who carried out their work mostly from home or $55 \%$ of their attendance by working from home, namely 128 respondents. This research is conducted from June $26^{\text {th }}$ to August $14^{\text {th }} 2020$. Respondents who have filled in the research instruments completely during that period are 117 respondens (91.40\%). Based on the research results, the characteristics of the respondents are obtained in Table 2 .

The descriptive respondent profile explains that women (57.26\%) are more likely to work from home than male respondents (42.74\%). Based on field observations, there are more male government employees work in offices than females, and most of these male respondents bring their own vehicles such as motorbikes and cars. Based on the age distribution of the respondents, the age range of 31 - 40 years (55.56\%) mostly worked from home, while very few respondents over 50 
Table 2. Number and Percentage of Respondent Characteristics

\begin{tabular}{|c|c|c|c|}
\hline \multicolumn{2}{|c|}{ Respondent Characteristics } & \multirow{2}{*}{$\begin{array}{c}\begin{array}{c}\text { Num. of } \\
\text { Employee }\end{array} \\
50\end{array}$} & \multirow{2}{*}{$\begin{array}{c}\text { Percentage } \\
42.74 \% \\
\end{array}$} \\
\hline Gender & Mens & & \\
\hline uenuer & Women & 67 & $57.26 \%$ \\
\hline \multirow{4}{*}{ Age } & $20-30$ years & 39 & $33.33 \%$ \\
\hline & $31-40$ years & 65 & $55.56 \%$ \\
\hline & $41-50$ years & 8 & $6.84 \%$ \\
\hline & $>50$ years & 5 & $4.27 \%$ \\
\hline \multirow{3}{*}{ Marital Status } & Single & 26 & $22.22 \%$ \\
\hline & Married & 89 & $76.07 \%$ \\
\hline & ever been married & 2 & $1.71 \%$ \\
\hline \multirow{4}{*}{ Last education } & Diploma & 4 & $3.42 \%$ \\
\hline & Bachelor & 69 & $58.97 \%$ \\
\hline & Masters & 43 & $36.75 \%$ \\
\hline & Doctor & 1 & $0.85 \%$ \\
\hline \multirow{4}{*}{ Length of work } & $<5$ years & 61 & $52.14 \%$ \\
\hline & $6-10$ years & 45 & $38.46 \%$ \\
\hline & 11 - 15 years & 5 & $4.27 \%$ \\
\hline & $>15$ years & 6 & $5.13 \%$ \\
\hline
\end{tabular}

Source : Primary data, processed (2020)

worked from home (4.27\%). Based on the marital status, respondents with married status have a large percentage (76.07\%) compared to respondents who are not married (22.22\%). This shows that most respondents who have families prefer working from home.

\section{Evaluation of Measurement Model}

Evaluation of the data in this study using PLS-SEM with the SmartPLS program. The latent variables in this study are leadership, organizational support, work environment and employee performance. Each of these variables has a manifest variable/ indicator that is reflective of the latent variable. PLS-SEM uses criteria that include two parts, namely the evaluation of the measurement model (outer model) and the structural model (inner model). The purpose of evaluating the measurement model is to measure how each indicator relates to its latent variable. Evaluation of the measurement model is done by testing the validity and reliability of each latent variable indicator. By starting an assessment of the measurement model, the researcher can believe that the latent variables or constructs that form the basis for assessing the structural model relationships are measurable and accurate (Hair, Sarstedt, Hopkins, \& Kuppelwieser, 2014)

Evaluation of the reflective measurement model should verify both the reliability and validity. The first step is using composite reliability to evaluate the construct measures' internal consistency reliability. The second step in evaluating reflective indicators is the assessment of validity. Validity focuses on convergent validity and discriminant validity. Convergent validity when each indicator has outer loadings above 0.70 and when each construct's average variance extracted (AVE) is 0.50 or higher. For outer loading, if there is an indicator used that has an outer loading value below the standard of 0.7 , it means that the indicator is invalid so it needs to be removed from the research model. (Hair et al. 2011).

After ensuring that no indicator has an outer loading below 0.7 , the next step is to calculate the construct reliability or composite reliability. Reliable when the composite reliability and/or cronbach's alpha value of more than 0.7 and the Average Variance Extracted (AVE) indicates that the construct validity with a 
standard value is greater than 0.5 (Hair Jr. et al. 2016). Based on the research results, the evaluation of Cronbach's Alpha, Composite Reliability, AVE are presented in Table 3.

The next evaluation is discriminant validity, which is carried out in two stages, Fornell - Larcker criterion value and cross loading. Discriminant validity is the construct measures what it is intended to measure. Discriminant validity by ensuring the AVE on each latent variable is greater than the other variables (Fornell - Larcker criterion) and the indicators for each variable must be greater than the other indicators (cross loadings) (Hair et al. 2011). Based on the research results, Fornell-Larcker criterion results are presented in Table 4.

The cross loadings value is calculating the correlation of indicators and their latent variables and other latent variables. The cross loadings value of each indicator in each variable is compared with other variables to determine the correlation between the indicators and each variable. The correlation value of the indicator to its latent variable must be greater than the correlation to other latent variables (Hair et al. 2014).

\section{Evaluation of Structural Model}

Once the reliability and validity of the outer models is established, the next step is evaluation of the structural model (inner model). The evaluation aims to evaluate the hypothesized relationships within the inner model, between latent variables and their constructs. Evaluation of the structural model by using of assessment coefficient of determination $\left(\mathrm{R}^{2}\right)$, validated redundancy $\left(\mathrm{Q}^{2}\right)$, and path coefficients (Hair et al., 2014). The $\mathrm{R}^{2}$ is a measure of the model's predictive accuracy. The $\mathrm{R}^{2}$ criterion of endogenous latent variables shows how much diversity of endogenous variables can be explained by exogenous variables. The endogenous variable in this study is employee performance while the exogenous variables are leadership, organizational support and work environment. The criteria for limiting the value of $\mathrm{R}^{2}$ in three classifications, namely the values of $0.75,0.50$ and

Table 3. Composite Reliability, Average Variance Extracted (AVE)

\begin{tabular}{lccc}
\hline \multicolumn{1}{c}{ Latent Variable } & Cronbach's Alpha & Composite Reliability & AVE \\
\hline Transformational Leadership & 0,946 & 0.953 & 0,662 \\
\hline Organizational Support & 0,927 & 0,941 & 0,629 \\
\hline Work Environment & 0,941 & 0,949 & 0,631 \\
\hline Employee Performance & 0,953 & 0,959 & 0,663 \\
\hline
\end{tabular}

Source: Data processed by PLS-SEM

Table 4. Fornell - Larcker criterion results

\begin{tabular}{lcccc}
\hline Latent Variable & $\begin{array}{c}\text { Transforational } \\
\text { Leadership }\end{array}$ & $\begin{array}{c}\text { Organizational } \\
\text { Support }\end{array}$ & $\begin{array}{c}\text { Work } \\
\text { Environment }\end{array}$ & $\begin{array}{c}\text { Employee } \\
\text { Performance }\end{array}$ \\
\hline Transforational Leadership & 0,793 & & & \\
\hline Organizational Support & 0,583 & 0,835 & 0,794 & \\
\hline Work Environment & 0,435 & 0,659 & 0,697 & 0,814 \\
\hline Employee Performance & 0,440 & 0,489 & & \\
\hline
\end{tabular}

Source: Data processed by PLS-SEM 
0.25 as substantial, moderate and weak. Based on the research results, $\mathrm{R}^{2}$ results are presented in Table 5.

Table 5. Coefficient of determination (R2)

\begin{tabular}{cc}
\hline & $\mathbf{R}^{2}$ \\
\hline Employee Performace & 0,5111 \\
\hline Source: Data processed by PLS-SEM &
\end{tabular}

The result indicate employee performance variable can be explained by variables in this research of $51.1 \%(0.511 \times 100 \%)$, while the remaining $48.9 \%$ explained by other variables outside of this study. $\mathrm{R}^{2}$ value of this study falls into the moderate category.

The next step to calculate the model structure is to use predictive relevance or cross-validated redundancy $\left(\mathrm{Q}^{2}\right)$ by using the blindfolding procedure in SmartPLS. The result show that the value of all latent constructs has a good predivative relevance, because the value is more than zero (0). The blindfolding results are presented in Table 6.

Path coefficient values are standardized on a range from -1 to +1 , with coefficients closer to +1 representing strong positive relationships and coefficients closer to -1 indicating strong negative relationships (Hair et al., 2014). Based on the research results, the evaluation of the path coefficient, mean, standard deviation and $t_{\text {statistics }}$ are presented in Table 7 and Figure 2.

Based on data processed of this research hence presented summary test result for all hypotheses in Table 8.

\section{Discussion}

The results of the research showed that transformational leadership has a positive and significant effect on employee performance at NPPA which means that transformational leadership can increase employee performance in working from home situation. This is in line with the research of Kowalski \& Swanson (2005) that the critical factor for the success of developing a work from home or teleworking program is management support from all levels in the organization, especially support from top management in the organization. Cascio (2000) states that in virtual offices such as telework or working from home, leaders have great challenges in implementing virtual working conditions. They must have the ability to determine performance, facilitate performance, and drive employee performance. Furthermore, Brunelle (2013) adds that in carrying out work from home,

Table 6. Validated Redundancy (Q2)

\begin{tabular}{lccc}
\hline Construct & SSO & SSE & $\mathbf{Q}^{2}$ \\
\hline Transformasional Leadership & 1404.000 & 619,520 & 0,559 \\
\hline Organizational Support & 819,000 & 332,462 & 0,594 \\
\hline Work Environment & 1287.000 & 574,079 & 0,554 \\
\hline Employee Performance & 1404.000 & 557,065 & 0,603 \\
\hline
\end{tabular}

Source: Data processed by PLS-SEM

Table 7. Results of the path coefficient, mean, standard deviation and $t_{\text {statistics }}$

\begin{tabular}{lcccc}
\hline \multicolumn{1}{c}{ Latent Variable } & $\begin{array}{c}\text { Original } \\
\text { Sample (O) }\end{array}$ & $\begin{array}{c}\text { Samlle } \\
\text { Mean (M) }\end{array}$ & $\begin{array}{c}\text { Standard Deviation } \\
\text { (STDEV) }\end{array}$ & $\begin{array}{c}\text { T Statistics } \\
(|\mathrm{O} / \mathrm{STERR}|)\end{array}$ \\
\hline Transforational Leadership & 0,185 & 0,189 & 0,072 & 2,560 \\
\hline Organizational Support & $-0,046$ & $-0,057$ & 0,113 & 0,409 \\
\hline Work Environment & 0,647 & 0,665 & 0,094 & 6,888 \\
\hline $\mathrm{t}(0,05)=1,96$ & & &
\end{tabular}

Source: Data processed by PLS-SEM 


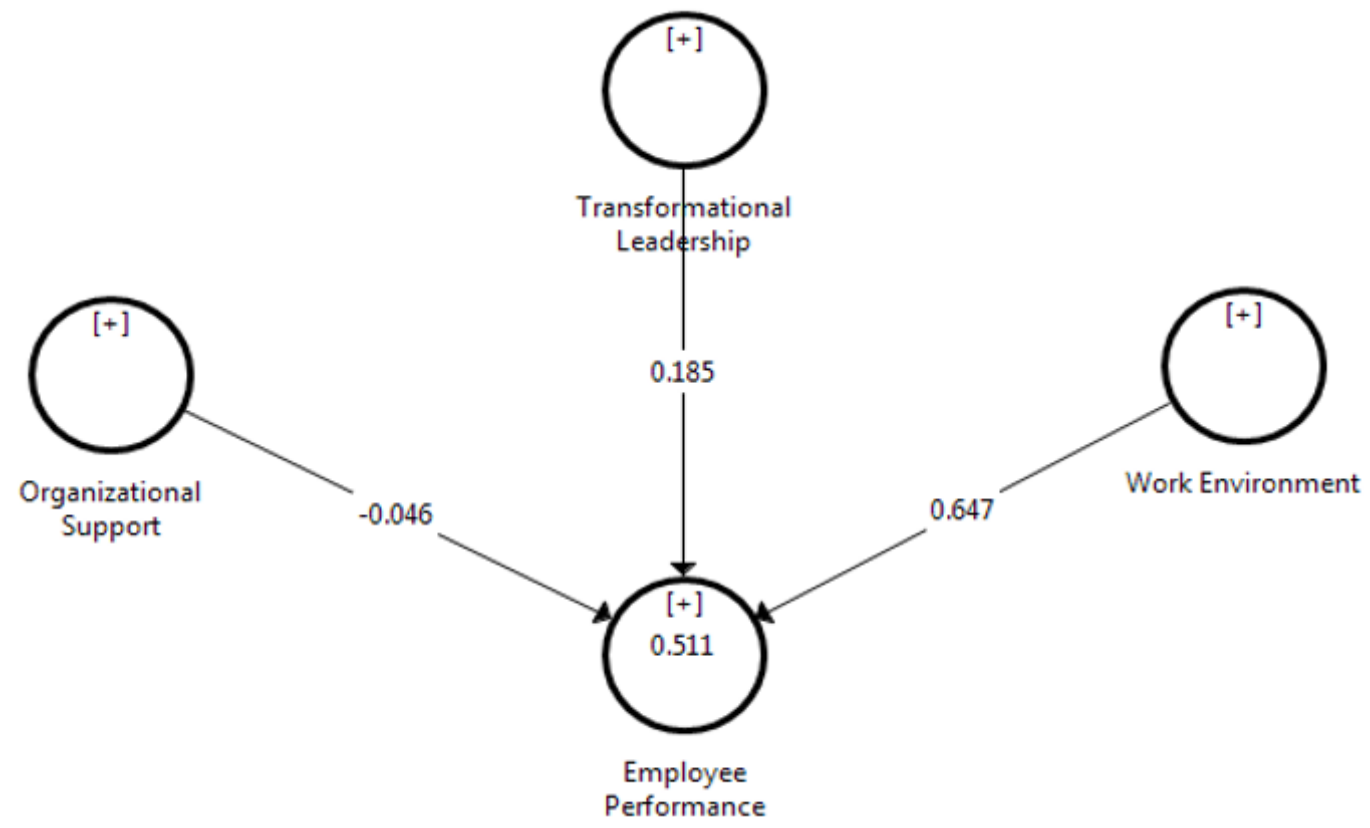

Figure 2. Path Coefficient

Table 8. Hypotheses Results

\begin{tabular}{lc}
\hline \multicolumn{1}{c}{ Hypotheses } & Result \\
\hline $\mathrm{H}_{1}:$ Transformational Leadership $\rightarrow$ Employee Performance & Supported \\
\hline $\mathrm{H}_{2}:$ Organizational Support $\rightarrow$ Employee Performance & NS \\
\hline $\mathrm{H}_{3}:$ Work Environment $\rightarrow$ Employee Performance & Supported \\
\hline Source: Data processed by PLS-SEM &
\end{tabular}

transformational leadership can moderate physical distance and psychological distance for employees. Transformational leadership is the type of leadership needed in the implementation of work from home or telework. Transformational leader can inspire followers to transcend their own self-interests and who are capable of having a profound and extraordinary effect on followers (Robbins \& Judge A, 2017).

Based on the research showed that the organizational support variable has a negatif relationship on employee performance at NPPA which means that organizational support does not affect employee performance in working from home situations. This is not in line with several studies including research by Baker et al. (2006), organizational support in home-based telecommuting and working from home or working remotely has 3 (three) categories, namely the use of technology, support related to the use of technology consists of training for telecommuting employees and variables other than technology consists of human resource department support and prior planning for telecommuting system. A successful implementation of telework policy, the organization must provide and upgrade the necessary IT infrastructure including high-speed internet and provide the necessary training for both 
managers and employees (Valmohammadi 2012). This fact is interesting and leaderds in NPPA should pay attention of it. This shows that organizational support has been optimal so that it does not affect employee performance. This is an input for leaders for understanding the needs of employees through an organizational support approach as research from Aboelmaged et al. (2012) stated that the critical factor that affects the productivity of organizations who work far away is the role of individuals and organizations or organizational support

The results of the research showed that work environment has a positive and significant effect on employee performance at NPPA which means that work environment can increase employee performance in working from home situation. This is in line with the research of Nakrošienè et al. (2019) that the most important factor affecting the outcome of remote work is the suitability of the workplace at home. One strategy to overcome the challenges of working from home is prepare a physical environment at home to be conducive so teleworkers can work comfortably, such as having a dedicated workspace (Greer and Payne 2014). According to Ng and Ng (2011) workers who are working from home want a quality work environment at home similar to a conventional office, such as having privacy, quality lighting, and adequate equipment. Based on the survey results, it is found that the work environment is the most significant variable affecting employee performance.

Based on the analysis conducted on the effect of transformational leadership, organizational support and work environment on employee performance, it is known that leadership and work environment have a positive and significant effect on employee performance, but on the other hand, organizational support does not affect or have an inverse effect on the implementation of work from home policies.

\section{MANAGERIAL IMPLICATION}

Based on the results of testing of all the hypotheses present in this study and discussion, as well as some conclusions which have been drawn then will be described how the implications of these findings. The role of transformational leadership has an important role in implementing the work from home policy in order to improve employee performance. Even though it is known that leadership has an effect on employee performance, NPPA must continue to provide guidance to these leaders. Management should increase the capabilities and managerial competence for leaders by training, coaching, mentoring or other assignment, especially to increase communication competence, competence development of self and others, and the ability to manage change. This is very important so that transformational leadership can have the competence to moderate work from home activities and reduce negative impacts.

Based on the results of research, organizational support has a negative relationship with employee performance. This finding of research is interesting and leaders in NPPA should pay attention about what employee's needs from organizational support. Management should monitor and evaluate current organtizational support such as the use of technology, support related to the use of technology and other variables besides technology. Management needs to carry out discussion activities to find out the needs of employees in implementing the work from home policy. The results of monitoring, evaluation and discussion can be used as input to provide organizational support to employee.

The work environment has an important role in improving employee performance in the context of implementing the work from home policy. Based on the research results, it is known that the work environment variable has the most significant role in implementing working from home. In this regard, recommendation to management is provide direction to employees maintain a conducive working environment at home. Space requirements and layout such as a room to work at home should 
have a special room that is separate from the busy area, quality lighting, and also work equipment to be noticed. This is intended to further improve employee performance while working from home.

Base on the number of employees who work from home, it is known that the total percentage of employees who work from home is $46.88 \%$. In this regard, the recommendation for management is to have a joint discussion to explore the success of work unit leaders who have successfully implemented work from home for their subordinates to become input for other work units that have not fully implemented working from home during the pandemic.

Another managerial implication from the research findings is management should make the Covid-19 pandemic a momentum to start changing employee habits. Activities carried out face-to-face can be transferred to face-to-face online via the internet. Management can begin to adjust flexible work systems and refer to employee performance (output based).

\section{CONCLUSION}

The results showed that the total percentage of employees in NPPA working from home is $46.88 \%$. Employees at work units who mostly work at home are employees at the Public Procurement Education and Training Center is the (93.33\%). The position of the government employee that mostly carries out working from home is Staff/Implementing Officer. This shows that not all work units have fully implemented the work from home policy. There are still many employees who are actively working in the office, so it has the potential to endanger the health of employees during the Covid 19 pandemic.
The characteristics of respondents in the study who carried out their jobs more by working from home is dominated by women (57.26\%), with the age distribution being dominated by the ages of 31-40 years (55.56\%), and the marital status is dominated by employees who are married (76.07\%). This shows that female employees prefer to work from home compared to male employees, furthermore it can be seen that married employees prefer to work from home. Employees 'awareness of working from home can reduce the spread of the virus, both for themselves and employees' families.

Based on the analysis conducted on the effect of transformational leadership, organizational support and work environment on employee performance, it is known that leadership and work environment have a positive and significant effect on employee performance, but on the other hand, organizational support does not affect or have an inverse effect on the implementation of work from home policies. Transformational leadership is the type of leadership that is most suitable for implementing a work from home policy. Organizational support has an inverse influence on employee performance. This could possibly occur because the variables used in this study have been optimally accepted by employees. Leaders should pay attention about what employee's needs from organizational support. Leaders and management should monitor and evaluate current organtizational support and the results can be used as input to provide organizational support to employee. The work environment has a positive and significant impact on employee performance in situations of working from home. This shows that the work environment for employees who work at home is physically suitable so that employees feel conducive to work from home. 
REFERENCES

Aboelmaged, M. G., Mohamed, S., \& Subbaugh, E. (2012). Factors influencing perceived productivity of Egyptian teleworkers : an empirical study. Measuring Business Excellence, 16(2), 3-22. https://doi.org/10.1108/13683041211230285

Agarwal, S. (2020). Leadership Style and Performance of Employees. International Research Journal of Business Studies, 13(1), 1-14. https://doi.org/10.21632/irjbs.13.1.1-14

Baker, E., Avery, G. C., \& Crawford, J. (2006). Home alone: The role of technology in telecommuting. Information Resources Management Journal, 19(4), 1-22. https://doi.org/10.4018/irmj.2006100101

Belzunegui-Eraso, A., \& Erro-Garcés, A. (2020). Teleworking in the context of the Covid-19 crisis. Sustainability (Switzerland), 12(9), 1-18. https://doi.org/10.3390/su12093662

Brunelle, E. (2013). Leadership and mobile working: The impact of distance on the superior-subordinate relationship and the moderating effects of leadership style. International Journal of Business and Social Science, 4(11), 1-14.

Burbach, M. E., \& Day, F. C. (2012). Does Organization Sector Matter in Leading Teleworker Teams ? A Comparative Case Study. International Journal of Business Research and Development, 3(1), 8-21.

Cascio, W. F. (2000). Managing a virtual workplace.: Discovery Service der Bibliotheken der RUB. 14(3). Retrieved from http://eds.a.ebscohost.com/eds/pdfviewer/pdfviewer?vid=2\&sid=d5152e6d-030b-449a-aff1-1f43ccad96f3\%40sdc-vsessmgr01

Chu, D. K., Akl, E. A., Duda, S., Solo, K., Yaacoub, S., Schünemann, H. J., . . Reinap, M. (2020). Physical distancing, face masks, and eye protection to prevent person-to-person transmission of SARS-CoV-2 and COVID-19: a systematic review and meta-analysis. The Lancet, 395(10242), 1973-1987. https://doi.org/10.1016/S0140-6736(20)31142-9

Coenen, M., \& Kok, R. A. W. (2014). Workplace flexibility and new product development performance: The role of telework and flexible work schedules. European Management Journal, 32(4), 564-576. https://doi.org/10.1016/j.emj.2013.12.003

Di Martino, V., \& Wirth, L. (1990). Telework: A new way of working and living. Int'l Lab. Rev., 129, 529.

Greer, T. W., \& Payne, S. C. (2014). Overcoming Telework Challenges : Outcomes of Successful Telework Strategies. 17(2), 87-111. https://doi.org/10.1037/mgr0000014

Hair, J. F., Sarstedt, M., Hopkins, L., \& Kuppelwieser, V. G. (2014). Partial least squares structural equation modeling (PLS-SEM): An emerging tool in business research. European Business Review, 26(2), 106-121. https://doi.org/10.1108/EBR-10-20130128

Kim, H. (2014). Transformational leadership, organizational clan culture, organizational affective commitment, and organizational citizenship behavior: A case of South Korea's public sector. Public Organization Review, 14(3), 397-417.

Kowalski, K. B., \& Swanson, J. A. (2005). Critical success factors in developing teleworking programs. Benchmarking, 12(3), 236-249. https://doi.org/10.1108/14635770510600357

Kurland, N. B., \& Bailey, D. E. (1999). Telework: The advantages and challenges of working here, there, anywhere, and anytime. IEEE Engineering Management Review, 28(2), 49-60.

Martin, B. H., \& MacDonnell, R. (2012). Is telework effective for organizations?: A meta-analysis of empirical research on perceptions of telework and organizational outcomes. Management Research Review, 35(7), 602-616. https://doi. org/10.1108/01409171211238820

Martínez-Sánchez, A., Pérez-Pérez, M., José Vela-Jiménez, M., \& de-Luis-Carnicer, P. (2008). Telework adoption, change management, and firm performance. Journal of Organizational Change Management, 21(1), 7-31. https://doi. org/10.1108/09534810810847011

Mustafa, M., \& Gold, M. (2013). "Chained to my work"? Strategies to manage temporal and physical boundaries among selfemployed teleworkers. Human Resource Management Journal, 23(4), 413-429. https://doi.org/10.1111/1748-8583.12009

Nakrošienė, A., Bučiūnienė, I., \& Goštautaitė, B. (2019). Working from home: characteristics and outcomes of telework. International Journal of Manpower, 40(1), 87-101. https://doi.org/10.1108/IJM-07-2017-0172

Ng, C. F. (2016). Public spaces as workplace for mobile knowledge workers. Journal of Corporate Real Estate, Vol. 18 No, 209-223. https://doi.org/DOI 10.1108/JCRE-10-2015-0030

Ng, C. F., \& Ng, C. F. (2010). Teleworker's home office : an extension of corporate office ? Emerald Group Publishing Limited, 28(3), 137-155. https://doi.org/10.1108/02632771011023113

Nilles, J. M. (1988). Traffic Reduction by Telecommuting: a Status Review and Selected Bibliography. Pergamon Press PIc, 22A(4), 301-317.

Pieterse, A. N., Van Knippenberg, D., Schippers, M., \& Stam, D. (2009). Transformational and transactional leadership and innovative behavior: The moderating role of psychological empowerment. Journal of Organizational Behavior, 31(4), 609-623. https://doi.org/DOI: 10.1002/job.650

Robbins, S. P., \& Judge A, T. (2017). Organizational Behavior (17thEditon ed.). London, England: Pearson Education Limited.

Valmohammadi, C. (2012). Investigating the perceptions of Iranian employees on teleworking. Industrial and Commercial Training, 44(4), 236-241. https://doi.org/DOI 10.1108/00197851211231513 
Vega, R. P., Anderson, A. J., \& Kaplan, S. A. (2015). A Within-Person Examination of the Effects of Telework. Journal of Business and Psychology, 30(2), 313-323. https://doi.org/10.1007/s10869-014-9359-4

World Health Organization. (2020). Preparing for large-scale community transmission of COVID-19. World Health Organization, (February), 1-8. Retrieved from https://apps.who.int/iris/bitstream/handle/10665/331243/COVID-19-02282020.pdf 